\title{
Crowned Dens Syndrome Associated with Hyperuricemia
}

\author{
Yuusaku Sugihara, Hiroko Ogawa and Fumio Otsuka
}

Key words: crowned dense syndrome, hyperuricemia

(Intern Med 58: 765, 2019)

(DOI: 10.2169/internalmedicine.1589-18)

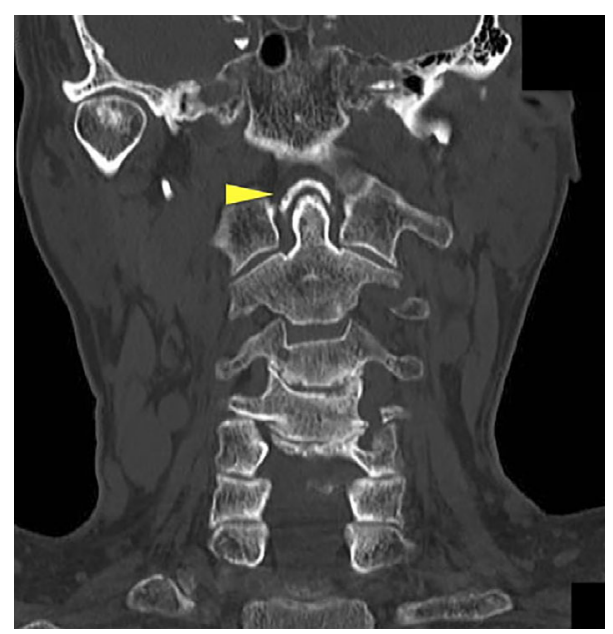

Picture.

A 71-year-old man presented to the hospital clinic with a 1-day history of cervical pain. He had been treated for hyperuricemia for the past 30 years. He had a very limited cervical range of motion because of the pain, but there was no redness, warmth, or swelling of the neck. The laboratory data revealed a C-reactive protein level of $2.15 \mathrm{mg} / \mathrm{dL}$ and uric acid level of $11.4 \mathrm{mg} / \mathrm{dL}$. Cervical computed tomography demonstrated calcification of the transverse ligament of the atlas (Picture, yellow arrowhead), and he was diagnosed with crowned dens syndrome. This is a rare disease characterized by the presence of calcification on the dens (1). Chondroid cells in the transverse ligament around the odontoid process cause the disease (2). The risk factors of this disease include age, joint trauma, serious illness, hemochromatosis, electrolyte abnormalities, and endocrine disorders. Treatment was initiated with an oral non-steroidal antiinflammatory drug. On day 8 , his symptoms of cervical pain disappeared.

The authors state that they have no Conflict of Interest (COI).

\section{References}

1. Bouvet JP, le Parc JM, Michalski B, Benlahrache C, Auquier L. Acute neck pain due to calcifications surrounding the odontoid process: the crowned dens syndrome. Arthritis Rheum 28: 1417$1420,1985$.

2. Tamura R, Takahashi S, Kamamoto D, Horikoshi T, Yoshida K. Crowned dens syndrome occurred in a patient after simple drainage for chronic subdural hematoma: a case report. NMC Case Rep J 4: 15-17, 2017.

The Internal Medicine is an Open Access journal distributed under the Creative Commons Attribution-NonCommercial-NoDerivatives 4.0 International License. To view the details of this license, please visit (https://creativecommons.org/licenses/ by-nc-nd/4.0/).

Department of General Medicine, Okayama University Graduate School of Medicine, Dentistry and Pharmaceutical Sciences, Japan Received: May 27, 2018; Accepted: July 25, 2018; Advance Publication by J-STAGE: October 17, 2018 Correspondence to Dr. Yuusaku Sugihara, y.sugi117@gmail.com

(C) 2019 The Japanese Society of Internal Medicine. Intern Med 58: 765, 2019 